\title{
Shari'a Police in Banda Aceh: Enforcement of Islam-based Regulations and People's Perceptions
}

\author{
Benjamin Otto and Jan Michiel Otto
}

\section{Researching the Wilayatul Hisbah (WH)}

In 2009, two weeks after I was given permission to do my research with the 'Shari'a police' (Wilayatul Hisbah/WH) in Aceh, I received a phone call that two perpetrators were caught. ${ }^{1}$ I was told that if I would like to interview them, I should come to the office immediately.

There he sits, at a table in the office of the Shari'a police, his face hidden behind his arms. My first respondent. I sit down next to him and ask him whether he is willing to answer some questions. He lifts his head. His face shows sadness, humiliation and despair, but he agrees to talk to me. He talks about his girlfriend, whom he plans to marry, that they slept together, how he was caught by the neighbours. He tells me how the neighbours beat him up, threw him into a rice field, pulled him out by his hair and insulted him non-stop. After this he was arrested by the Shari'a police. His left eye is swollen, as well as his lips and cheekbone. I feel sympathy for this man. All he did was have sex with the woman he loves, but he has been punished severely; physically and socially. Although I know about the strict prohibition of premarital sex in Aceh, this punishment feels disproportionate and unjust. At the end of the day I drive my motorcycle back to my house in the outskirts of Banda Aceh, my head filled with new information, contradictory emotions and thoughts about how to process all of this in my thesis. I pass the warung kopi (coffee shop) in

1 Benjamin Otto is a criminologist who conducted field research on the Sharica police in Aceh. He currently works for the Amsterdam police force and volunteers for Amnesty International (Amsterdam office) as country coordinator for Indonesia. When this chapter refers to 'I,' 'me' or 'my' it is Benjamin. Jan Michiel Otto is professor of law and governance in non-Western countries and director of the Van Vollenhoven Institute for Law, Governance, and Development at Leiden University. He has published about Sharía and national law in Indonesia and other Muslim countries. 
my kampung (neighbourhood), where I recently made new friends. We usually have a drink there, two or three times a day. The atmosphere is relaxed. The warung is like a second living room for all the men of the kampung. Here they brag about their newest sexual conquests and discuss the football results from the day before. My friends are sitting there as they always do. My thoughts still with the poor man who was beaten up so severely and who is awaiting his punishment at the Shari'a police office, I join them. Taking a sip of sweet tea, one of the guys says: "Too bad you went home early yesterday. There was a couple having premarital sex just around the corner. We got them really hard."

These are my field notes from April 2009, describing the first case I encountered during my research on the implementation of Sharia-based criminal law by the Sharía police in Aceh. The fact that Aceh province introduced a series of Shari'a-based regulations at the dawn of the twenty-first century has prompted extensive critique both within Indonesia and around the world. International media have reported on several of Aceh's new provincial regulations, including the introduction of punishments such as caning, which critics have argued are cruel and unusual. ${ }^{2}$

The case refers in the first place to the way in which the 'Shari'a police' in Banda Aceh, the provincial capital, implement provincial legislation on khalwat, the prohibition of unmarried and unrelated men and women spending time together in an enclosed space without supervision (Qanun No. 14 /2003). The official name of what is often referred to by outside observers as the 'Shari'a Police' is Wilayatul Hisbah; often called by its acronym wH (pronounced 'way hah' in Indonesian). ${ }^{3}$ The case shows some of the complexities of this topic. The WH turns out to be not only a repressive police force; it can also act, in the case of excessive violence by community members, as a protector of perpetrators. Also striking is the ambiguity of people who on the one hand can react explosively when neighbours are caught committing khalwat, and on the other hand

2 In 2009, Aceh's provincial legislature passed a bill mandating even harsher physical punishments, including the stoning of convicted adulterers. The governor, however, refused to sign the bill into law and it has thus never been implemented. For more on this, see Großmann (this volume).

3 The Wilayatul Hisbah is not actually defined as a 'police force' in Aceh's provincial Shari'a legislation. In practice, however, the institution appears at times as a kind of police force because of its joint operations with the civilian police (Kesatuan Polisi Pamong Praja, or Satpol PP). However, in common parlance they are also known as the 'Shari'a Police.' 
can be proud of having had premarital sex themselves. The main question of my research was how the Sharia-based law on khalwat was implemented by the WH, what the consequences were for ordinary people in Banda Aceh, and how people perceived these consequences. Meanwhile, as an inhabitant of a small kampung on the outskirts of Banda Aceh, I could also observe how local community members had their own time-honoured ways of dealing with people transgressing local norms.

When I arrived in Banda Aceh in March 2009, the place was completely new to me. However, Indonesia as a country was familiar. In 1989-1990, at the age of four, I lived for a year in a kampung in North Bandung, where I went to pre-school and played with Indonesian friends. Ten years later, I went back for a holiday trip and was happy that some of my old kampung playmates had remained friends. In 2005, then a student of criminology at VU University in Amsterdam, I went to Yogyakarta to study Indonesian (Bahasa Indonesia). I also carried out volunteer work at the local Legal Aid Bureau. Living for six months in a small middle-class neighbourhood, talking with friends, neighbours, colleagues, and driving around town on my motorcycle, I came to learn some lessons about Islam, crime, laws, and the police in contemporary Indonesia.

I learned, for example, that for many Muslims in Yogyakarta it was considered important to be a good, pious Muslim and to follow the Shari'a (in the sense of 'God's path') and that some people did their best to break with their own frivolous pasts by trying to behave piously (see also Kloos, this volume). I also learned that there were many laws in Indonesia, some of them quite repressive, others protective, but that in practice evading the law was a national pastime, or sometimes even a necessity. It was not only the common people who did this; some policemen, officials and judges also routinely violated legal rules, or applied them arbitrarily. When dozens of motorcyclists were ordered to stop to have their driving licenses checked, some were formally punished, while others could bribe their way out. Some others again, were able to just pass, as the police decided not to bother them-seemingly because of their appearance as possibly well-connected persons (for example if the driver was, like me, exceptionally tall and of a white complexion). At the Legal Aid Bureau, I noticed how the police arrested people and intimidated them, which is a violation of the law. I also learned about all kinds of social rules, commonly referred to as adat (tradition, or customs), to which people were supposed to comply. Nevertheless, in spite of state laws, Islamic rules and adat norms, both crime and violations of religious and adat norms (including gambling, drinking, and prostitution) were not uncommon in certain circles in Yogyakarta. In fact, it sometimes seemed to me that, at least in 
some contexts, extramarital and premarital sex were as common in Islamic Indonesia as in libertarian Amsterdam.

My observations of such patterns of lawlessness were perhaps not new. Many legal anthropology studies of Indonesia have discussed the ineffectiveness of the legal system. One major line of argument in such work has been that state law is a modern phenomenon, foreign to indigenous communities and naturally bound to meet much social resistance rooted in local traditions (Von Benda Beckmann 2002). However, in Aceh the issue seemed to be a different one. Here the state, through the initiatives of provincial and local governments, has tried to impose new religion-based legal rules on today's society. Would such appeals to religion and/or custom in state law have more legitimacy, and would it therefore be implemented more effectively here? After Bandung and Yogyakarta, I was curious about the limits of law in Aceh, and especially of criminal regulations derived from Shari'a. How were these rules implemented? What was their effect? Moreover, how did the project of state Shari'a implementation relate to informal community action, including the kind of vigilante violence referred to in the example above?

In order to find answers to such questions, I first went to the courts and to the prosecutor's office to find out how many cases had actually been prosecuted, forwarded to the courts, and how many cases had resulted in actual punishments. In this way, I also hoped to locate perpetrators, and to interview them about their punishments and their perceptions of the Sharia-based law and the $\mathrm{WH}$. This was not a great success. To my surprise, I found that the last case in which someone had been formally prosecuted was in 2007 , and that for more than two years after that not a single case had been forwarded to the court in Banda Aceh for prosecution. I did collect a few names and addresses of former perpetrators but I found that these people had moved away without leaving their new addresses. Once, I had a door slammed in my face. Clearly, this was not a subject people liked to be reminded of. It turned out that I could not start my research with the perpetrators directly, and I had to begin at the other end, with the law and its agents. Thus, I decided to focus on the work of the $\mathrm{WH}$, and particularly on their patrols and their raids. Fortunately, the WH allowed me to observe their routines and practices. Over a period of five months, I spoke to dozens of people about the Shari'a-based criminal law and its implementation. In this period, I came to know about nine cases of people being apprehended for committing khalwat. I spoke to all of the perpetrators involved in these cases.

It is important to note that my research was carried out in the city of Banda Aceh. The implementation of Aceh's Sharica-based regulations, which are formally named qanun, is not uniform everywhere across the province of 
Aceh, and there are considerable fluctuations in the rate of cases brought to court. As mentioned above, there has not been any caning since February 2007 in Banda Aceh, whereas in Langsa (East Aceh), 53 people were caned in the year 2011 alone. ${ }^{4}$ Most of the community members I interviewed were men. For women especially, it is very shameful in Aceh to talk about having had sex before marriage. For me as a male foreign researcher, it was almost impossible to discuss the subject with women. In several cases, however, I had the chance to talk to both the male and female perpetrators at the same time, so this gave me the opportunity to interview some women as well. As a consequence the results presented in this chapter are based mainly, but not exclusively, on male inhabitants of Banda Aceh.

The next section sketches the legal background of the khalwat regulation and how it was supposed to mark a new era in law-society relations in Indonesia. In the third section, we will discuss the work of the $\mathrm{WH}$, by focusing on its three main tasks: patrols, raids, and investigation of suspected khalwat cases. Section four deals with the question of what happens to the people who get caught for committing khalwat and how this experience is perceived by them. In the fifth section, to illustrate in more detail the actual practice of implementing the khalwat regulation in Banda Aceh, we will present a more extensive description of one of the nine cases encountered during the fieldwork. In the sixth section, we discuss some of the ways in which ordinary people think and talk, on a day to day basis, about the wH and Aceh's Shari'a-based penal law. Finally, in the concluding remarks we will try to interpret the impact of the Sharia-based penal law on daily life in Aceh.

\section{The New Shari'a-based Regulations in Aceh}

Until 1999, Indonesian law was 'made in Jakarta' and aimed at 'development' (pembangunan). Development under the New Order (1966-1998) stood for stability, economic growth, and a certain degree of redistribution. Suharto and his generals viewed law as an instrument of power and development policy. Law would help the government's orders be carried out in orderly ways, and pre-

4 It is important to note that the years 2007-2010 were a pronounced low-point in terms of formal Shari'a criminal cases brought to court. There was, however, a temporary resurgence in some districts (kabupaten) in 2011-particularly in the run-up to the elections. Whereas my fieldwork was carried out from March to August 2009, I conducted an Internet-based survey of local Acehnese newspapers in the summer and autumn of 2011, to learn about recent court decisions and punishments throughout Aceh province. 
scribe how people would become 'developed' (Lev 2000). With regard to both adat and Islamic law, Suharto's government was ambiguous. Adat law was formally recognized but in the practice of land administration it was often denied or overruled by the government (Safitri 2010). Shari'a was controlled by the New Order government by incorporating acceptable versions of it into national law, for example in the 1974 Marriage Act, and in the 1989 Religious Courts Act. Such measures, however, generally dealt exclusively with the administration of Islamic family and inheritance law. In Aceh, however, there already were precedents for official promulgation of Sharia criminal legislation over the past half century (Feener 2013).

Aceh had been granted special autonomy status in 1959 in the domains of culture, religion, and education, as result of the Darul Islam rebellion, which ended in 1962. During the Suharto era, provinces and districts still had some legislative autonomy on paper, however in practice this was extremely limited. Governors and district heads used to receive 'prefab' draft-regulations from Jakarta in the form of a directive (pedoman) ready to be enacted. In short, although the New Order government promoted the image of Indonesia as a 'Negara Hukum' (state based on the rule of law), law-making was undemocratic, the bureaucracy including the police was authoritarian and quite corrupt, the judiciary had lost its independence and was also corrupted whereas the government regarded human rights as an instrument of subversion, and legal aid as suspect. From the perspective of common people in search of justice, the better option was generally to try and 'fix' or 'negotiate' things with the administration through brokers or mediators rather than rely on the court system.

After the fall of Suharto in 1998, new efforts were made to realize the national idea of a Negara Hukum. Constitutional amendments reduced the role of the military in government, and strengthened democratic mechanisms, the roles of parliament and of the courts vis-à-vis the executive. A bill of rights was introduced. In 1999, Law 25 on regional autonomy gave districts and towns a considerable degree of autonomy to regulate their own affairs. Fear of separatist tendencies in the provinces of Aceh and Papua led the central government to granting special authorities to both provinces, allowing local administrators to create their own regulations. ${ }^{5}$ Law No. 18/2001 on Aceh enabled the province to base its regulations on Shari'a. This was in line with a long tradition of the Acehnese taking pride in their reputation for being among the country's

5 For a more extensive discussion of the relationship between Islamic and national law in contemporary Indonesia, see Otto (2010). 
most committed Muslims - as reflected in the popular soubriquet for Aceh, 'the Veranda of Mecca' (Serambi Mekkah). The province of Aceh had already once successfully demanded special status in the 1950s. The effect of that earlier special status had remained limited, but the ambitions of the special autonomy provisions of the post-Suharto period were higher.

In these developments, Aceh's provincial branch of the Indonesian Ulama Council (MUI, later re-established as M PU) played an active Islamizing role by issuing several fatwas. In 2002 and 2003, Aceh's State Sharía Agency (Dinas Syariat Islam/DSI), then led by Alyasa Abubakar, professor of religious studies at the State Islamic Studies Institute (IAIN, presently UIN) Ar-Raniry in Banda Aceh, was (among others) involved in the preparation of draft provincial regulations, referred to locally as qanun. Soon thereafter, the provincial parliament enacted several qanuns based upon those drafts. The two most relevant to this chapter are Qanun No. 11/2002, notably its subsection concerning Islamic dress codes, and Qanun No. 14/2003 on khalwat, which prohibits unmarried couples to be together in a secluded place. The sanctions contained in Qanun 14 are threefold, namely fine, imprisonment, and caning. The legislator has framed the latter typically as a provision of criminal state law (tazir) bearing no reference to the Qur'anic punishment of the hudud-crime of adultery (zina). Here, it may be noted that in nearby Malaysia, which in many ways has functioned as an example for the formal implementation of Shari'a law in Aceh, the Islamic judiciary has been increasingly modelled on the generally more prestigious civil judiciary (Peletz 2013). Caning, moreover, is quite common in Malaysia and Singapore, including in non-Islamic contexts, being a legacy of British colonial law rather than an outcome of Islamic regulations (Lindsey et al. 2007, 245246).

\section{Getting to Know the wH}

The physical condition of their office in Banda Aceh is very telling of the situation of the WH. On 1 January 2009, the WH moved from the well-maintained DSI premises to a lesser office, on the compound of the Mayor's Office, close to the offices of the Local Government Police, the Kesatuan Polisi Pamong Praja, generally known as Satpol PP, of which the wH formally became a unit. Remarkably, on 12 May 2009, the wH changed location again, allegedly because its office was to be renovated. The new building was in an even worse condition. Parts of the ceiling looked as if they could fall down any second and there were big cracks in the wall. The building they had used previously had not been very impressive either, but compared to the current place it had looked much bet- 
ter. Before 2009, when the WH was still part of the DSI, they had been located in a brand new complex. The rapid deterioration of their housing conditions seemed to be a reflection of the political priorities of the provincial government.

The WH is the 'police unit' responsible for upholding the provincial Shari'abased regulations. The first legal document describing the wH's role was the general elucidation of Qanun No. 11/2002, the introduction of which reads as follows:

The Wilayatul Hisbah as a supervisory institution is granted the role of warning, guiding, and advising, so that the cases of contravention of this Qanun that are submitted to the investigators, to be followed up and forwarded on to the courts, are cases that have been through a process of warning and guidance toward the offender.

Two years later, this was specified further in the Governor's Decree 1/2004 on the Establishment and Functions of the WH. This Decree stipulates that the role of the WH includes: a) providing guidance and spiritual advocacy, including informing the public of qanun relating to Shari'a; b) monitoring compliance with Sharica legislation; c) rebuking, warning and providing moral guidance to those suspected of violating the Shari'a; d) trying to stop activities/conduct suspected of violating the Shari'a; e) settling violations through a village customary meeting (Rapat Adat); and f) transferring violations of the Shari'a to the police who are legally responsible for conducting investigations of criminal offences (UNDP et al. 2006, 48-49). Interestingly, none of these tasks really make the $\mathrm{WH}$ seem like a 'police force' in any conventional sense, as there are no provisions for arrest, detention, and the like.

Although the WH was created on paper as early as 2000 (Qanun No. 5/2000), it only became active in the field after the December 2004 tsunami. At first, only the provincial capital Banda Aceh had a wH unit, but one year later district offices had been established all over the province. There were other important changes as well. Originally, the $\mathrm{WH}$ was placed directly under the State Shari'a Agency. However, in January 2009, the wH was formally integrated with the public order police, the Satpol PP. The wH itself does not have the legal power to enforce the Shari'a-based regulations. For this, they need the support of the Satpol PP. To arrest, detain or even enter a living space, the presence of a Satpol PP member is a requirement. Co-operation between the WH and the Satpol PP is therefore prerequisite to enforce Aceh's Sharia-based criminal regulations. However, the different institutional and social backgrounds of the two forces and its officers has made this very difficult to achieve. During my 
research, I noted that members of both units often regarded each other in a negative way. The Satpol P P was regarded by members of the WH as a bunch of rude, non-believing and violent men, whereas Satpol PP officers considered the members of the $\mathrm{WH}$ as "weak, hypocritical people without any explicit authority." ${ }^{6}$ As one wH official put it: "They are rude people. They are also not happy with us. As soon as the Director is not around, they enjoy annoying and insulting us." ${ }^{7}$

In order to get to know the modus operandi of the $\mathrm{wH}$, I joined their daily patrols. Although not all the patrols were the same, the following description from my notes gives a good insight into the daily work of the wH officers.

The next day I go back to the office. I have been told that patrols are held three times a day. For safety reasons I am not allowed to join the wH officers in the patrol car, but I can follow them on my motorbike to see how they work and how the citizens react. The patrol is not as exciting as I thought it would be. We drive around for one hour, only stopping once. There is a big empty building where young couples could hide to seek some privacy, which is of course forbidden according to the law on khalwat. We search the building, without finding anybody. On the way back nothing much happens. Occasionally a WH officer shouts from the back of the pick-up truck to a woman that she should wear a headscarf. The woman either shrugs or looks away a bit ashamed. In any case it doesn't matter too much, because the pick-up truck continues its way back to the office. Back in the office I find out that the work of the WH officers is pretty much limited to the three daily patrols. In between these patrols, the officers sit around, drink coffee, and talk. This gives me a perfect opportunity to get to know these officers and learn about their backgrounds.

The starting qualifications to get a regular, salaried job at the $\mathrm{WH}$ are twofold. One needs to be able to demonstrate a general proficiency in Quranic literacy, and one should have a bachelor degree from a university. ${ }^{8}$ After a while, I found out from my daily conversations in the wH office that the employees are not all equally pious and motivated to do their work. Some really hoped to contribute to the Islamization of Aceh, while others were interested only in their monthly paycheck. These differences were also clear when I observed the

6 Personal communication with a member of the Satpol PP, June 2009, Banda Aceh.

7 Personal communication with a member of the wH, June 2009, Banda Aceh.

8 Interview with an administrative staff member of the wH, Banda Aceh, April 2009. 
officers doing their job. Some WH officers explained the Shari'a regulations to young couples with a lot of conviction and sincere belief, while others preferred to stay in the back of the car as often as possible. A good example of an officer with a seemingly relaxed attitude toward the task of Islamizing society is presented in the next quote. This is what this officer said five minutes after the patrol started: "Wow, it's pretty hot. It looks like there will be no perpetrators today."

During my research, I witnessed three main practices through which the unit tried to uphold Sharia-based law: daily patrols, clothing raids, and investigations of people suspected of committing, or having committed, khalwat. I will now describe three cases, one for each practice, in order to show how the wH tried to fulfil its task.

\section{The Patrol}

Occasionally the $\mathrm{WH}$ officers were assigned a specific task for their patrol. Visiting 'beauty salons' (salon) is an example of such a task.

"Hey hey, it's 9 o'clock, we are leaving," the shift leader shouts. The wH officers gather around and get into one of the two departing pick-up trucks. I ask the shift leader where we are going today. He tells me that we will go to Peunayong, a district in the city centre, to check upon some beauty salons. Usually we drive around the city without a specific destination, so I am excited that I will get to see something new today. We arrive at the first salon. I join the five officers who enter the salon to see what they will do. The other fifteen officers wait outside in the truck. An intimidating transvestite (bencong) sits inside and asks us provokingly whether we want a massage. One of the officers starts to interrogate her. He asks whether there is prostitution, whether she closes during Friday prayer, whether this is indeed a women-only salon and similar questions. ${ }^{10}$ The others look around. I join one of them upstairs. There we find several small rooms with mattresses on the floor. In one of the

9 Interview with a senior wH officer, June 2oog.

10 Because of the Sharica regulations it is forbidden to run mixed gender beauty salons. Women should be treated by women and men by men. In practice, an exception is made for transvestites: they can work in both male and female salons. Most of the salons are female salons, but almost all have a second floor with small rooms and mattresses, which suggests that there is also a male clientele. 
rooms, four young, barely dressed girls are resting. As soon as they see me, they start shouting: "Mister mister, you like me? Mister mister, come back, come here." It seems pretty clear to me that I have just seen my first Acehnese brothel. I ask one of the officers why they don't act upon this discovery. He answers that the girls could also be family or employees. He can only close the shop when the prostitutes are caught in the act. We thank the owner for her time and go back outside. This ritual is repeated a few times. After visiting five or six salons we head back to the office. Time for coffee.

During my research, all the salon check-ups were carried out during the morning shift. Although the odds of catching the prostitutes red-handed would probably be higher on a night patrol, the WH never did this. Curious about the WH officers' view, I suggested that they conduct this salon check in the evening, but none of them considered this to be a good idea. I could only conclude, then, that the wH did not really want to stop the prostitution in Peunayong, but they did want to pretend that they tried to stop it. Although I asked several wH officers, I was not able to find out whether the WH was actually ordered or pressurized to tolerate prostitution and if so, by whom, or whether they had other reasons for not closing down these poorly disguised brothels.

The wH usually went out on patrol three times a day. A few officers would stay at the office to answer the phone while the rest joined the patrol. The description above is an example of what the officers did during a patrol. Also, they often looked for hidden stashes of alcohol or for young couples trying to find some privacy in romantic places such as the pier in the harbour district of Ulee Lhee. Another regularly chosen option was to just drive around for an hour, shout at some unveiled women to put on a headscarf, and return to the office. The average duration of a patrol was about one hour. If female officers joined the patrol, they always sat in a separate car.

\section{Clothing Raids}

Besides the daily duty of going on patrol, the wH occasionally organized a raid (razia). This meant that they set up a road block to check if passers-by were wearing proper Islamic clothing. The following two descriptions of one such raid are taken from my field notes of May 2009.

"These pants are too tight. I can see the shape of your legs," an officer blurts. "You are not being a good Muslim." During the raid almost all 
the women and occasionally a man or two are pulled off the road to be lectured about the way they dress. About 80 per cent of the women passing are dressed improperly, according to the WH officers. Although almost all of them are covered from the ankle to the neck and most of them also wear a headscarf, they still don't pass the Shari'a dress code.

According to the Sharia regulations, women should be dressed in accordance with Islam, which is generally interpreted as being completely covered except for their feet, hands and face. ${ }^{11}$ In addition to this, the shape of the body should not be visible through the clothes. This automatically excludes jeans and many other 'western-style' clothes. For men, the dress code is less strict. Men should be covered up from knee to belly button. However, bare-chested men are a regular sight in Banda Aceh and that is not considered very shocking.

When stopped on the road, the women have to hand over their identity card ("КтР"). Then they get a five-minute lecture from one of the WH officers about how decent Muslim women should dress. None of the women speak up. Some bow their heads in shame, while others look angry or annoyed. I try to interview some women. The ones that are ashamed prefer to leave as soon as possible. The others are willing to talk. They tell me that they don't agree with these raids. They feel discriminated against because only women are being lectured. They also feel violated in their right to dress the way they want. And most of all they feel the $\mathrm{WH}$ is being hypocritical. They have read in the newspaper about a WH officer caught for having sex with a high-school girl and other scandals. Now they are being lectured by officers from the same institution about the way they dress. They feel wrongly accused and that upsets them. After being lectured the women are allowed to pick up their KTP. They have to register before their card is returned and they are allowed to continue on their way. After two hours the wH calls it a day. Hundreds of forms are completed with names of improperly-dressed women and no arrests have been made.

11 Qanun No.11/2002, article 13(1) states that "Every Muslim is required to dress in accordance with Islam (Setiap orang Islam wajib berbusana Islami)." The latter is defined as wearing "clothes that cover one's aurat (intimate parts of the human body), which are not transparent, and which do not show the shape of the body (pakaian yang menutup aurat yang tidak tembuspandang, dan tidak memperlihatkan bentuk tubuh)." 
During the five months in which I observed and followed the WH in Banda Aceh, only two such 'clothing raids' were organized. What happened with the names of the women who were lectured was unclear. I never saw anyone process these forms in a computer programme or check the names of the first raid with the names of the second raid. Strangely, whereas Aceh's Islamic dress codes have been discussed all over the world, I found that the actual impact of these raids seemed rather marginal. Their infrequency, the lack of actual punishments, the fact that the wH looked upon virtually all women as perpetrators, and last but not least the outcome that in general women in Banda Aceh did not seem to change the way they dress; all these factors contributed to the marginality of such official state enforcement measures. Obviously, in this case the state-sponsored 'Shari'a norms' went far beyond commonly accepted practices. At the same time, as we have seen already at the beginning of this chapter, (particular segments of) local communities had their own, sometimes violent, way of defining, and dealing with, moral transgressions.

\section{Investigations}

The third part of the wH job, which potentially had a much greater impact on the lives of those people targeted, was to respond to tips from Banda Aceh citizens about the whereabouts of couples arrested for (or suspected of) committing khalwat. The wH often received phone calls or text messages from worried or upset neighbours. Whenever the tip was considered serious, the wH set out for the given location to take the perpetrators into custody. On rare occasions, the wH themselves caught people in the act during a patrol, such as in the case of a 'rocking car' in the harbour district, ${ }^{12}$ but in most cases they depended on tips from the residents of Banda Aceh.

The following field notes from July 2009 show that the wH depended not only on the tips of the local population to make an arrest, but also on their permission to do this.

The last patrol of the day is already over and I sit with the WH officers who await the end of their shift. Every now and then a text message comes

"Mobil Goyang," Serambi Indonesia (1 June 2009). In this case, the wH spotted a wobbling car during their patrol. Officers approached the car to see what was going on. When they reached the vehicle, they found two people having sex in the car. These two people were immediately arrested. 
in with reports of people committing khalwat. No action follows. They believe them to be just prank messages. Then the phone rings, and this time it seems like there is an actual case. After a short discussion, the shift leader decides we have to pull out. When we arrive at the 'crime scene' a lot of people have already gathered around the two suspects. One of the WH officers questions the witnesses and the head of the kampung. I notice there is a vivid discussion, for some people disagree completely with the officer. After ten minutes the WH officers retreat. They tell me that the kampung security men have decided to solve this matter themselves. ${ }^{13}$ They do not allow the WH to take the suspects into custody.

This case shows the limited power of the WH. Although Qanun No. 14/2003 aims to discourage premarital sex, the $\mathrm{WH}$ cannot do much without the permission of the villagers. In this particular case, the villagers preferred to solve the matter themselves. But in other cases, I was told by villagers that the wH had been called by angry community members and requested to arrest the suspect. There were also cases, as we have learned from the first case discussed in this chapter, in which the violence used by local people against the suspects was so brutal that concerned villagers asked the $\mathrm{w} H$ to arrest the suspects for their own safety.

Whether local community members want the WH to intervene or not depends on several factors. Usually a distinction is made between original inhabitants of the kampung and 'people from outside' (orang luar, or pendatang), that is, recent newcomers. When perpetrators originate from the kampung where they are caught, the matter is generally solved 'within the family' (secara keluarga) or 'according to custom' (secara adat) between the neighbourhood leader (Geuchik or Kepala Lorong), ${ }^{14}$ the family and sometimes some

13 Many kampungs have their own security arrangements. Usually all the (young) men from the kampung (pemuda kampung; literally 'village youth') take turns patrolling at night. This may be once a week or every other week.

14 All over Indonesia local administration is divided into several levels. Towns (kota) like Banda Aceh and rural districts (kabupaten) are divided into sub-districts (kecamatan). Sub-districts have offices headed by the Head of the sub-district, the Camat. Physically, a sub-district hosts a number of kampungs, a kind of urban villages, which have a name, a history, a community and local leaders with which the kampung dwellers identify. Administratively, sub-districts are further divided into local units which, in rural areas, are called 'villages' (desa). The heads of these units, the Village Heads (Geuchik/Kepala Desa) are popularly elected, and have an office, a staff, and some consultative bodies of community members. Aceh's Regional Regulation No. 7/2000 on the Establishment of Adat Life employs the Acehnese adat term Geuchik to refer to the Village Head rather 
respected members of the kampung. ${ }^{15}$ Among the nine cases I observed there was not a single case in which the person arrested by the wH was an original inhabitant of a kampung. The arrested perpetrators were always 'outsiders.' This can be explained by the absence of a family to solve the problem in a family way, and by a lack of personal concern among community members for the fate of an 'outsider.' Other factors can influence the decision to call the wH as well. The availability of a WH unit nearby or the local tradition to solve problems within the community are factors that influence this decision. The type of violation can also be important. If the offense is not considered that severe, the choice is often made to solve the matter within the kampung. When the crime is considered pretty serious or the offender has already been caught several times, the chances of the $\mathrm{wH}$ being called in increase.

\section{Patterns of WH Practices of Dealing with Perpetrators}

In the previous sections, I introduced the $\mathrm{WH}$, its main tasks, and the atmosphere in which its officers carried out their work. In this section, I will analyze in more detail the third task, which is the investigation of accused perpetrators of the khalwat prohibition. From my field research, I gradually found out that the WH had developed its own ways of dealing with perpetrators of the Sharia-based khalwat regulation. Although every case was slightly different, I was eventually able to recognize a clear pattern. Based on my nine case studies, as well as various conversations and observations, the wH's practice regarding khalwat investigations may be schematized in nine distinct 'steps' or 'phases.' These are: 1) discovery, 2) internal handling, 3) 'arrest,' 4) detention and inter-

than the Indonesian term Kepala Desa (UNDP 2006, 50). Below this level, a form of neighbourhood organization has been established throughout Indonesia. In cities, the subdistricts are not divided in desa but in so-called kelurahan, the head of which (Lurah) is not elected, but is an appointed official. Below the level of desa/kelurahan, at the grassroots level, a few dozens of houses are grouped together as a neighbourhood block called lorong (literally 'alley'). Their head, a community member, is elected and called Pak Lorong. Pak Lorong is the voluntary local leader who provides a regular connection between the officials of the desa/kelurahan office and the members of their community.

15 Solutions like these commonly involve a 'peace making' ritual (perdamaian), featuring a public apology, possibly in combination with the imposition of a fine. Village leaders might go further, however, for example by pressuring the accused couple and their families into getting married on the spot (that is, at the nearest mosque). 
rogation, 5) calling the family, 6) calling the press, 7) lecture by wH director, 8) reporting to the $\mathrm{WH}$, and 9 ) stigmatization.

1) The discovery: $\mathrm{wH}$ officers rarely discovered a khalwat case themselves. ${ }^{16}$ Thus, they were almost completely dependent on worried, jealous, or upset people (often neighbours) to tell them where they could find wrongdoers. The case mentioned in the introduction shows how brutal violence could occur when unmarried couples were caught by their neighbours in moments of illicit intimacy. Later, I learned that one neighbour was so worried about the perpetrators being beaten up that she called the $\mathrm{WH}$. She figured that the arrival of the wH would stop the violence and bring them to safety.

When I asked one of the attackers in this case why they had reacted so brutally, he answered:

When people have premarital sex, the whole kampung will be contaminated with this $\sin$ (kena dosa). Later all the villagers will be punished [by God] for that $\sin$ (dihukum untuk dosa ini).

The same man had told me several times before that he had had sex with more than one woman in his life, although he was not married. I could not understand the difference between him having premarital sex and his bragging about it in the coffee shop on the one hand, and his angry and aggressive reaction when he caught someone else committing the same 'crime' on the other hand. When I confronted him with my lack of understanding, he answered, with a serious tone:

Actually having sex before marriage is forbidden. It is indeed a sin. When you get caught you will be beaten for sure. But when nobody finds out, it's ok.

This is an interesting example of how some young Acehnese men dealt with strict Shari'a regulations. Not all men I came to know in Aceh shared this opinion, but it seemed that everyone had to find a way of coping with the incompatibility of the temptations of everyday life and the desire to be a self-respecting Muslim. I could also deduct from the way this man and his

16 Often, young couples were found sitting in a secluded place outdoors. Apparently, these violations often were not considered severe enough to arrest and detain the suspects. In the nine cases I investigated, all suspects were caught while being together in isolation inside a house or building. 
friends talked about what happened that punishing perceived wrongdoers was something they enjoyed doing. Beating up a 'sinner' brought a lot of excitement to the village and they considered it a legitimate way to express some aggression or frustration.

2) Internal handling:The head of a kampung was always informed when people were caught committing khalwat. He decided how the case should be settled and whether the wH should be called. There were several ways, I was told by local kampung dwellers, to solve the problem 'according to custom (adat).' One was by paying money, to be used for the common good. Another settlement involved ritual 'bathing' (dimandikan). The perpetrator would be literally washed with water, which symbolized washing away the sin. Less friendly were the solutions in which the perpetrators were 'washed' with sewage water or subjected to different forms of humiliation and/or physical violence. ${ }^{17}$

3) The 'arrest': After the perpetrators were handed over by the head of the kampung, they were taken into custody by the wH. In all the cases I witnessed, the perpetrators were apprehended without violence. Officially, the wH did not have the legal authority to arrest and detain people. However, in practice this was often ignored. Even with the consent of the Satpol PP, WH officers were not allowed to detain people suspected of committing khalwat, but many people are unaware of this. Practices like 'bathing' the perpetrators may be seen as adat punishments. However, involving the wH meant that the conflict was not to be solved internally, on the basis of adat law alone.

4) Detention and interrogation: At the WH office, couples suspected of committing khalwat were separated and questioned to determine what had happened exactly. Detention could last from a few hours to a few days. During the interrogation, dubious methods were often used to find out the 'truth.' Threats, lies and insinuations were not uncommon. Alternatively, $\mathrm{WH}$ officers would lecture the suspects about religion. How much pressure was put on the suspect depended on the officer. Again, the wH did not have the official authority to detain people. Therefore, they used an alternative method. They did not lock the perpetrators up, but forbade them to leave the office area. By taking away their identity card, threatening them with prosecution and not informing them about the absence of legal grounds for such detention, perpetrators were de facto detained. In one

17 See Kloos (2014) for an elaborate discussion of handling khalwat violations within the kampung. 
of the cases, a young student accused of committing khalwat told me that he did not have the slightest clue whether he was to be detained for a day, a month or a year.

5) Calling the family: As in adat law settings, close family members were called in to discuss what should happen with the perpetrators. Should the latter be forced to marry, or forbidden to meet again? Should they be punished at home as well, or was the arrest itself sufficient punishment? Usually the suspects were asked to contact their family to report to the station. Preferably the parents were called, but in cases in which they were not available, an older brother, uncle or even a nephew would do as well. In one of the cases I studied, both suspects had no family left because of the tsunami. The wH did not know how to solve this matter without family, so they handed the suspects over to the regular police. There, the unhappy couple stayed incarcerated until they gathered enough money to bribe themselves out.

6) Calling the press: Local journalists told me that they always got phone calls from the WH when a new couple was arrested for committing khalwat. Usually they wrote about the nature of the crime and the circumstances in which it occurred. When I asked at the WH office why the newspaper always had to be notified, a WH officer answered that this would prevent other people from doing the same. For many perpetrators this form of publicity was the worst part of the punishment. People were very ashamed when they were accused publicly of committing khalwat. As one suspect told me, "I am already ashamed enough towards my family and kampung. Why should all the people in the city be informed? Besides, it could cost me my job if my boss finds out."18

7) Lecture by the WH director: In the seventh phase, typically a meeting was held, chaired by the director of the local wH office, to decide what should happen to the perpetrators. In those instances I witnessed, the WH director was talking 90 per cent of the time, using the occasion to lecture them once more about their immoral behaviour. Usually the perpetrators stayed silent and nodded quietly, responding only when they were asked something. When the families from both sides and the director had decided on the fate of the perpetrators, and they themselves had promised not to make the same mistake again, they were released. 
8) Reporting to the $W H$ : The release was not unconditional. At the Banda Aceh WH office, the accused had to return to the $\mathrm{WH}$ office at regular intervals thereafter to report in. In most cases, three such visits were stipulated. During these visits, they were lectured again about their misbehaviour and about the purpose of Islam. The perpetrators were free to choose when to come back, but their KTP would only be returned after the third visit. One of the perpetrators from my case studies reported twice, but did not feel like reporting again. Instead he went to the civil registry and applied for a new KTP, which he received two weeks later.

9) Stigmatization: After the suspects were released, the real punishment was often yet to start. As a result of the publication in the local newspapers, many other people were aware of the events that happened. In one case, the perpetrator was forced to leave his kampung. In another case, a perpetrator was allowed to stay, but nobody wanted to talk to her anymore. She eventually decided to leave the kampung herself, since, as she described it, "My neighbours don't talk to me anymore. Even the one I used to be close with does not dare to be friends with me anymore."19 One girl was also suspended by her local school. She was photographed by the local newspaper wearing her school uniform. The school claimed that she had given it a bad reputation, and expelled her. A man involved in another case, who was held for two days, lost his job. As he described it, "I could not come because I was caught, and many people would like to work where I work. When I did not come the second day either, my boss gave my job to someone else." Although many people did not comply with the Shari'a-based penal regulations, the stigmatization of those who were caught was typically a cause for great worry, especially when it concerned khalwat, which was considered a very bad sin. Just as in the case of the man from my kampung, whom I quoted above, sometimes the difference between acceptable and immoral behaviour seemed to be a matter of being able to avoid being seen and caught.

This pattern shows how the wH developed its own particular practices in the absence of formal prosecution by the public prosecutor and adjudication by the Islamic courts. This practice is not based on any official policy to deal with khalwat perpetrators as such, but the WH developed it by applying the limited means they had at their disposal. Whereas the abovementioned sequence of nine phases was applied in almost all cases observed during my field research, there were also exceptions. For instance, there was one case in which a perpe-

19 Interview with a female khalwat perpetrator, 5 May 2009, Banda Aceh. 
trator was a friend of a well-known politician. This powerful friend arranged that the press would not publish an article in the newspaper about the case.

\section{Being Caught by the wH}

In this section, we would like to provide some insight into the experiences of those who were apprehended by the WH. Of course, the cases I studied were all different. The facts of the cases varied considerably, the backgrounds of the people who got caught were diverse and their ages also varied. Yet, from the nine cases observed, a few generalizations can be made about the people who were caught by the $\mathrm{WH}$ and how they felt about this. In the first place, those arrested were almost never powerful people. Secondly, their knowledge of Islamic regulations was often very limited. Thirdly, they usually did not know what their rights were and what punishment awaited them. In the fourth place, in almost all the cases I studied, the perpetrators were very ashamed of the situation they found themselves in.

In order to give some insight into the feelings of a perpetrator, we will now discuss the case of 'Adi.' ${ }^{20}$ It is a 'typical' case in the sense that it shares the four features mentioned above with many other cases. Yet, Adi's case also has some special features. Firstly, Adi was a very serious young Muslim who tried to live his life as well as possible in accordance with his religion. Secondly, in his perception, he had done nothing wrong. It was only because the wH imposed its official interpretation of Islam on him that he was forced to see himself as a 'bad Muslim.' Thirdly, he was lucky enough to be released before the reporters arrived, so no article was published in the newspaper. Finally, long after the arrest, he still suffered from the humiliation and the shame he felt when accused of committing what many people saw as one of the worst sins in their religion. What follows are some selected field notes on Adi's case. $^{21}$

After having joined another patrol, one of the officers tells me that there are new perpetrators I can interview for my research. I join a young man and try to talk with him. His name is Adi, and he is 25 years old. He barely answers my questions and does not look up a single time. He keeps silent and it is clear that he is very upset because of everything that has

20 For privacy reasons all names of respondents have been altered for this chapter.

21 Field notes, 4 May and 18 May 2009, Banda Aceh. 
happened in the past hour. I realize that I cannot interview someone who is this upset, so I get up and tell him that I will be leaving. For the first time he looks me in the eye. Quietly he asks me to stay a little longer. I sit down again.

After an hour Adi starts to talk. He tells me about his life, his family and his girlfriend. How happy she makes him and that he wants to marry her. He seems to be a serious young man. He studies diligently and is a good football player. He has often been asked by different teams to play matches for them. This is how he makes his money. Adi has been dating a girl for three years now. He is still head over heels in love with her. Everything seemed to go well, when suddenly his life was turned upside down. When he was talking with his girlfriend in his room suddenly the WH appeared. They were both arrested and locked up in separate rooms.

Adi is scared, he does not know what will happen to them and he is worried about his girlfriend. Although he thinks he has done nothing wrong, he feels guilty about bringing this shame upon his girlfriend. He is afraid that she will (be forced to) leave him because of this. He has never slept with her. Adi wants to wait until they get married. We talk all night long and I try to comfort him by telling him that they probably will not be caned and will be released the next morning. Then Adi asks me whether I can send a message to his girlfriend in the other cell. He types a text in Acehnese in his telephone and hands it over to me. I walk to the guards and tell them I would like to interview the girl as well. In the cell I try to talk to the girl and show her the message from her boyfriend. But she is so upset, that she does not look at me nor listens to what I'm saying. After a few minutes she finally realizes that I have a message from her boyfriend. At the moment I want to give her the phone with his message a guard comes in. He tells me that I cannot be alone in the cell with this woman according to Shari'a law. This situation "comes close to illicit sex" he says, "please continue interviewing the boy." I head back to Adi and tell him I did not succeed. Nothing seems to calm him down, until he finally falls asleep.

The next morning the families of both 'sinners' arrive. They are not happy with the arrest of their children, but they are smart enough to hide their displeasure. They behave in polite ways and give the socially acceptable answers so that they can leave as soon as possible. The director of the WH and the two families agree that the two kids should no longer be allowed to be in the same room without an elder to keep an eye on them. 
A few days later, I try to contact Adi, but he does not answer his phone. Two weeks later during a football tournament, I see that Adi is playing for the opponent team in my second match. I say hello, but he pretends not to see me. After the game I approach him again, but as soon as he sees me, he walks away. I do not understand this, because I thought he had become sort of a friend. I ask one of his friends, who is a shared acquaintance, why he is acting like this. My friend tells me that Adi is trying to continue his life and does not like to be reminded of the incident. Even more importantly, he does not want other people to find out what has happened. He is willing to talk to me, but only if I promise not to tell a single soul.

Certainly, shaming perpetrators, which is commonly regarded as an effective sanction in traditional adat communities, is also a considerable element of state Shari'a reinforcement in contemporary Aceh.

\section{The General Public's Perceptions of the wH}

In the previous section, we have seen what people go through, step by step, after they have been caught by the $\mathrm{WH}$ and how they respond to the situation. I found that perpetrators did not know beforehand what was going to happen to them. From interviews with other people in Banda Aceh, who had never been caught, it turned out that they too had little idea about how the wH actually handled cases. They did know, however, what the wH was established for and almost everybody had an opinion about it. Although not everybody thought the same way about the WH, several opinions and thoughts seemed to be widely shared among the population. These were the things that, during my five months of field research, I heard over and over again.

Among the people of Banda Aceh, the dominant opinion about the WH was not positive. First of all, the WH is seen as a police unit. Due to the general malfunctioning and corruption in the Indonesian police, and bureaucracy in general, the wH was automatically assumed to be malfunctioning and corrupt as well. Secondly, people felt that the actions of the WH were severely biased. In particular, women and poor people felt discriminated against. As one of my interlocutors told me:

It is not fair that it is always just the poor people who are caught and punished. The law of Sharia [that is, local Shari'a regulations] is not fair, because rich people never get caught. People with money can just 
pay and the problem is over. Poor people without money go to jail straight away or get caned. ${ }^{22}$

In a rather similar fashion, a female interlocutor blamed the $\mathrm{wH}$ for being discriminatory, asking: "Why always harass women instead of catching real criminals?"23

Another point raised by many people in Banda Aceh was the alleged immoral behaviour of certain WH officers themselves. In the past few years, there have been several newspaper reports about wH officers caught for adultery or premarital sex. On 19 April 2007, a 33 year-old wH officer was caught cheating on his wife with a 17 year-old high-school girl in a public toilet in Ulee Kareng, Banda Aceh. ${ }^{24}$ Although he was caught red-handed, he was never caned or sentenced. On the night of 10 January 2010, three officers in Langsa allegedly raped an arrested suspect. ${ }^{25}$ Although only a few cases of misbehaving WH officers had been reported by a newspaper, it was clear that the reputation of the institution had been ruined.

Many of these criticisms were confirmed by my field observations. Indeed, I did not see wealthy people being questioned at the wH office, or being caught during clothing raids for 'un-Islamic' ways of dressing. At the same time, I wondered why people's irritations and criticisms were invariably aimed at the $\mathrm{WH}$, and not at the law which the $\mathrm{WH}$ has been assigned to enforce. For example, Article 22 in Qanun No. 14/2003 about khalwat gives the judge the discretionary power to prescribe either caning or fining as a punishment. However, fines are so high that the majority of the people can never afford to pay them. As a result, they will inevitably be caned. In the rare occasion that rich people have been caught and prosecuted, this has never resulted in a public caning. The rich can often buy their way out without being shamed publicly. In 2006, however, a politician - a member of the DPRD (District Assembly) of North Aceh-was arrested and sentenced to be caned. He appealed as many times as possible, but was never able to change the verdict. Still, the sentence was never executed. This is legally possible, because the law implements no timeframe that regulates when the punishment should be

\footnotetext{
22 Personal communication, unskilled worker (approximately 40 years old), June 2009, Banda Aceh.

23 Personal communication, Acehnese woman (approximately 30 years old), who was stopped during a raid in May 2009. I heard many similar complaints during the raids from women who were halted as well as from bystanders, both female and male.

24 "Ketika Polisi Syariat Berbuat Mesum," Detik News, 20 April 2007.

25 "Sharia Police Arrested for Rape," The Jakarta Post, 12 January 2010.
} 
executed. Therefore, officially this man still awaits his sentence, but nobody believes this punishment will ever be carried out.

To put it more generally, most people seemed to be largely unaware that it is the law itself which is discriminatory. Another obvious example is the dress code, which is much stricter for women than for men, and thus forces the wH to focus on women. Still, women do not complain so much about the law itself, but rather about the fact that they feel harassed. As for the oft-heard complaint that the WH does not arrest the rich perpetrators, it was my impression that people often did not realize that the WH simply lacks the authority and resources to enter private houses where the rich supposedly violate the Sharia-based regulations, as well as other means required to do their job properly.

\section{Concluding Remarks}

This chapter has discussed Aceh's Shari'a-based regulations, especially the 2003 Qanun on khalwat, illicit behaviour between two members of the opposite sex. It shows how both local communities and the wH enforce Islamic moral norms as set forth in Aceh's state Shari'a legislation. Finally, it presents evidence of the critical discourse ordinary Acehnese draw upon when they speak about the $\mathrm{WH}$, and about the state Sharica system more generally.

Some scholars of Aceh's Islamic legislation have focused on how the laws fit in Indonesia's legal system, notably from a human rights perspective. Lindsey et al. $(2007,254)$ have concluded that, "Shari'a in Aceh is thus an old theme but very new as a legal system [...] The question now is how will it develop?" Others asked similar questions such as "[h]ow far will implementation of 'comprehensive sharia' proceed in Aceh?" (Nur Ichwan 2007, 210). While some of the first reports in 2005-2006, including that of the International Crisis Group (2006), rang the alarm bell about the Shari'a-based regulations, pointing at a range of serious human rights violations by the wH's predecessor, more recent observers suggest that "the implementation of this ideal has so far been less than complete" (Nur Ichwan 2007, 214). This chapter establishes some basic information about how 'it has developed' and 'how far the implementation has proceeded' in Banda Aceh. It must be noted that our findings definitely cannot be generalized across the whole province. However, they do provide concrete empirical data that can be of significant value in helping to understand the everyday workings and popular perceptions of this contemporary Islamic legal system.

So how do we assess the impact of the khalwat regulation and the way it has been enforced in Banda Aceh? To put things in perspective, we should make 
three observations. First, Aceh has a long tradition of taking pride in its culture, its way of being Islamic, and its claims to political autonomy, distancing itself from broader Indonesian national values. In many interviews, people made clear that they are firstly Acehnese, secondly Muslims, and thirdly Indonesian. Second, compared to the many years of bloody civil warfare between the Free Aceh Movement (GAM) and the Indonesian army, and to the humanitarian disaster of the 2004 tsunami, the newly introduced Sharia-based law simply has much less impact. Whilst some people showed me their discontent, their critiques were mostly moderate. Third, the use of physical violence against men and women who violate local norms concerning sexuality is not new in Aceh; rather, it is a long-established element of local culture.

When we look at the Shari'a-based legislation as a whole, it is striking that political support for the Islamization of law is far from unanimous in Aceh. Aceh's legislature, the DPRA, which was elected in 2009 and dominated by former associates of the Free Aceh Movement (organized in Partai Aceh/PA), had not been very enthusiastic about such legislation. The former provincial Governor, Irwandi Yusuf (PA), even refused to sign the 2009 qanun enacted by the outgoing DPRA, which prescribes the punishment of stoning (rajam) for debauchery (zina) (see Großmann, this volume). Within the state apparatus, the WH does not rank very high. It is part of the regional public order police force, Satpol PP, which has less power and a lower status than the national police force. The wH lacks the basic legal authorities of a police unit, such as arrest and detention, and even within the Satpol PP, the WH does not stand in high regard.

Our study shows that the WH implemented and enforced the regulation on khalwat in three ways, namely through patrols, raids, and arrests after being informed by local communities. In Banda Aceh, as we saw in this chapter, the patrols and raids had very little effect. Field observations revealed an almost mysterious reticence on the side of the wH when it came to closing down brothels and the like (for which, obviously, they could have invoked the Satpol PP). The khalwat incidents, however, which were handled by the Banda Aceh WH about twice a month on average, did have considerable impact on the lives of the individual perpetrators. The wH's involvement of their families, and especially of the press, tended to stigmatize the perpetrators, affecting their social and economic position badly.

By intimidating the accused and keeping them uninformed about their situation, the WH in Banda Aceh has developed its own quasi-policing practice, without formally transferring cases to the police and the public prosecutor. During the process, it applies its own system of 'enforcement' consisting of the nine different stages described in this chapter. A close analysis of the actual 
relations between the $\mathrm{WH}$ and local communities and their leaders reveals the extent and limits of local authority. Local leaders, whether Kepala Kampung, Geuchik, or Pak Lorong, simply decide whether they transfer a case to the WH or not. And if the WH itself takes charge, they solve the matter in a much more informal way-working with local community leaders and the families of the accused, rather than by any kind of formal legal or Shari'a-based procedure. In fact, most literature on the introduction of Sharia-based law in the 20012005 period seems to have overlooked the fact that, at the same time, other relevant regulations were enacted, such as Perda No. 7/200o on the Establishment of Adat, Qanun No. 4/2003 on the Mukim governance structures, and Qanun No. 5/2003 on the Gampong governance structures. These by-laws serve to strengthen and formalize the role of traditional local community leaders in solving local conflicts, disputes, and other problems (UNDP 2006, 49-51), thus framing the work of the wH further. While the mandate of the wH has been constrained by weak legal powers vis-à-vis Satpol PP and other police units, the WH is also plagued by a lack of resources and a bad reputation among the population.

What, in conclusion, are the consequences of the state Islamic legal system for ordinary people living in the province's capital city, Banda Aceh? For most ordinary people, it seems, the consequences are quite limited. In many parts of the town patrols or raids by the wH never take place. In such areas, I saw women in their own neighbourhoods without headscarves, and in the outskirts of town I saw boys and girls sitting together without any apparent fear of reprisal. In the town centre and along the main roads, people do appear to pay some attention to the new rules. Yet, although patrols and raids intimidate and disturb people who are on their way, all the fuss usually results in just a verbal warning. Meanwhile, Acehnese are convinced that elsewhere, behind closed doors, drinking, gambling, and prostitution continue to occur, and that especially rich and influential people are never caught and punished by the wH. Therefore, if the goal of the state Shari'a project is to effectuate a drastic behavioural transformation to the extent that 'immodest' clothing, extramarital sex, drinking, gambling and prostitution would disappear, then the WH clearly has not been able to achieve its goal. So far, it has not been able to impose a set of strict socio-religious views and practices on a whole population. Instead, it seems that people mostly stick to their old ways, and that the impact has been rather modest.

At the same time, according to our findings, people who are caught committing khalwat can face serious consequences-even if the WH may treat them better than the local community. The end result of the wH's shaming policy is often sad for the 'perpetrators': a serious love affair must end, people feel 
the urgent need to move immediately to another area, or one loses his or her job or place in an educational institution. The case studies also show that the chances of being caught are much higher for 'outsiders', who do not belong to the local community. In one exceptional case, the perpetrator seemed not to be affected at all by the $\mathrm{WH}$, and did not really care about changing his behaviour. Finally, we asked how people perceive the $\mathrm{wH}$, the Shari'a-based law and the way it is implemented. Although some respondents enthusiastically expressed support for the wH's hard line on immorality, the interviews reveal considerable discontent, focusing on the way in which the law is enforced. In general, the image of the $\mathrm{WH}$ is negative. People's discontent concentrates on what they see as discrimination toward poor people and women, coupled with the view that the $\mathrm{wH}$ officers themselves do not practice what they preach. Due to some incidents reported in the press, and because members of the police are generally seen as corrupt, wH officers are often portrayed as hypocritical sinners with double standards. ${ }^{26}$ Since the gap between prescribed norms and effective practice is rather common in Indonesia, the discontent is only moderate; particularly because people have been more concerned with other graver matters related to the resolution of armed conflict and the consequences of the tsunami.

When asked about the Shari'a itself, people usually reacted in a positive way. Since Islam in their view is by definition something good, the same goes for the divine law. It is not up to humans to have critical opinions about it. In this sense, people cannot but praise Allah and extol the virtues of Islam, and this also seems to apply to the Shari'a as well. However, the relation between religion, Sharica-based norms, and local cultural norms turns out to be very complex. In fact, people are more ambivalent than they appear to be when they just speak about Islam and Sharia. As was noted in the introduction, people condemn others on the basis of strict norms, which in practice they themselves do not comply with. It seems that they tolerate or even endorse non-compliant behaviour as long as it takes place in secret. Clearly, double standards prevail in communities too. For when I asked people in favour of a strict law on khalwat

26 "Mengaku petugas wH perkosa remaja putri" (Confession of wH official raping young girl), http://indonesiaindonesia.com/f/75320-mengaku-petugas-wh-perkosa-remaja-putri/

(Accessed 24 February 2013); “Kasus mesum anggota wH belum diproses hukum” (Sexual offence case of wH member not yet in legal process), http://www.antaranews.com/ view/?i=1185878646\&c=NAS\&s= (Accessed 24 February 2013); "Berbuat mesum seorang polisi syariah NAD ditangkap warga" (Police official committing sexual offence in Aceh Province caught by community), http://www.antaranews.com/print/1176971136/berbuat -mesum-seorang-polisi-syariah-nad-ditangkap-warga (Accessed 24 February 2013). 
whether-if they were to be caught - they would prefer to be dealt with by the WH or have the matter settled 'according to custom' (secara adat), they invariably said that they preferred to have the matter settled 'by custom.'

On the political aspects of the Shari'a system, moreover, many people in Aceh are indifferent. As noted above, the introduction of all Shari'a-based laws cannot be said to be 'the expression of the aspiration of the Acehnese,' since their elected political representatives are seriously divided on the issue. In addition, people do not take the trouble to investigate the substantive content of the province's Islamic legislation. This also helps to explain why people hold the $\mathrm{WH}$ responsible for discriminatory behaviour, without realizing that this is at least in part caused by the law itself. Additionally, people do not often discuss the fact that Aceh's newly acquired legislative autonomy has not only led to the reinforcement of religion, but also strengthened adat as a basis for law and conflict resolution. In this context marked by ambiguities of all kinds-legal, political, administrative, religious or cultural - the WH in Banda Aceh has definitely not become a fanatical Saudi-styled 'morality police,' as some had feared. Its implementation of the Shariaa-based khalwat regulation has manifested itself mostly in moral stigmatization rather than physical punishment. Moreover, the WH has mostly targeted lower classes. While the WH is accepted because of its religious foundation, its particular forms of implementation have provoked considerable criticism. When it comes to sanctioning misbehaviour, people value the continuing presence of local leaders and traditional adat rather than the bureaucratized $\mathrm{WH}$. As a result, the $\mathrm{WH}$ effectively lacks the power to truly transform society.

\section{References}

Benda-Beckmann, F. von. 2002. "Who is Afraid of Legal Pluralism?" Journal of Legal Pluralism and Unofficial Law 47:37-82.

Feener, R. Michael. 2013. Shari'a and Social Engineering: The Implementation of Islamic Law in Contemporary Aceh, Indonesia. Oxford: Oxford University Press.

International Crisis Group. 2006. Islamic Law and Criminal Justice in Aceh. Asia Report No. 117, Jakarta/Brussels.

Kloos, David. 2014. "In the Name of Syariah? Vigilante Violence, Territoriality, and Moral Authority in Aceh, Indonesia." Indonesia 98:59-90.

Lev, D.S. 2000. Legal Evolution and Political Authority in Indonesia. Den Haag: Kluwer Law International.

Lindsey, T. and M.B. Hooker, with Ross Clarke and Jeremy Kingsley. 2007. "Shari'a Revival in Aceh." In Islamic Law in Contemporary Indonesia: Ideas and Institutions, 
edited by R.M. Feener and M.E. Cammack, 216-256. Cambridge: Harvard University Press.

Nur Ichwan, Moch. 2007. "The Politics of Shariatization: Central Governmental and Regional Discourses of Sharia Implementation in Aceh." In Islamic Law in Contemporary Indonesia: Ideas and Institutions, edited by R.M. Feener and M.E. Cammack, 193-215. Cambridge: Harvard University Press.

Otto, J.M. 2010. "Sharia and National Law in Indonesia." In Sharia Incorporated: A Comparative Overview of the Legal Systems in Twelve Muslim Countries in Past and Present (Law, Governance, and Development), edited by J.M. Otto, 433-490. Leiden: Leiden University Press.

Peletz, Michael G. 2013. "Malaysia's Syariah Judiciary as Global Assemblage: Islamization, Corporatization, and Other Transformations in Context." Comparative Studies in Society and History 55(3):603-633.

Safitri, M.A. 2010. "Forest Tenure in Indonesia: The Socio-Legal Challenges of Securing Communities' Rights." PhD diss., Leiden University.

UNDP. 2006. Access to Justice in Aceh. Making the Transition to Sustainable Peace and Development in Aceh. Report made in partnership with the Agency for Rehabilitation and Reconstruction, the National Planning and Development Agency, The Syiah Kuala University, IAIN Ar-Raniry, the International Development Law Organization, and the World Bank. 